\title{
Piotr Lorens
}

Politechnika Gdańska, Wydziat Architektury

e-mail: plorens@pg.gda.pl

\section{Scenariusze rozwoju przestrzennego obszaru metropolitalnego Trójmiasta}

\begin{abstract}
Zarys treści: Artykuł dotyczy problematyki kształtowania struktury funkcjonalno-przestrzennej obszaru metropolitalnego Trójmiasta. Zawarto $w$ nim rozważania dotyczące uwarunkowań przekształceń, możliwych wariantów rozwoju oraz ich konsekwencji. Analiza istniejących uwarunkowań obejmuje obecną sytuację w zakresie głównych koncentracji zainwestowania, planowane przekształcenia w zakresie infrastruktury transportowej oraz możliwości i tendencje przekształceń obszarów zdegradowanych. Na tej bazie opisano cztery najbardziej prawdopodobne warianty scenariusza przekształceń obszaru. Opis każdego z wariantów scenariusza przekształceń obejmuje przedstawienie założeń przestrzennych, przesłanek niezbędnych dla jego urzeczywistnienia, omówienie możliwego stanu wynikowego oraz konsekwencji jego realizacji. Podsumowaniem artykułu są wnioski dotyczące elementów koniecznych do realizacji scenariusza oraz konsekwencji ich ewentualnej wybiórczej realizacji.
\end{abstract}

Słowa kluczowe: obszar metropolitalny Trójmiasta, suburbanizacja, rozwój zrównoważony, miasto kompaktowe, scenariusze rozwoju

\section{Wprowadzenie}

Celem artykułu jest określenie możliwych wariantów przekształceń struktury funkcjonalno-przestrzennej obszaru metropolitalnego Trójmiasta, przy szczególnym uwzględnieniu konsekwencji wiążących się z problemem suburbanizacji. Takie ujęcie zagadnienia wynikało $\mathrm{z}$ faktu, że problem rozlewania się struktury aglomeracji zaczyna być postrzegany jako zagrożenie dla jej integralności, a tym samym dla konkurencyjnej pozycji całej metropolii. Jednakże zjawisko to wynika z szeregu przyczyn natury globalnej oraz warunkowane jest szczególnym charakterem struktury przestrzennej regionu ${ }^{1}$. Wpisując się $w$ generalne tendencje przemian przestrzeni, warunkuje także (oraz równocześnie jest po części warunkowane) możliwości wiążące się z lokalizacją nowego programu miejskiego na terenach zdegradowanych, w obrębie których wdrażać można programy odnowy

Więcej na ten temat m.in. w: Lorens (2005b), Kozłowski (2006). 
przestrzennej oraz - w niektórych wypadkach - kompleksowej rewitalizacji. Elementem tych programów jest też intensyfikacja istniejących struktur, co często wiąże się z wypełnianiem rozmaitych przestrzeni „opuszczonych” oraz zagospodarowywaniem tzw. „nieużytków miejskich”.

Punktem wyjścia dla tych rozważań stała się szersza analiza problemu suburbanizacji w kontekście przemian współczesnego miasta, zwłaszcza tzw. miasta postsocjalistycznego. Na tej bazie syntetycznie określono obecną sytuację obszaru metropolitalnego Trójmiasta, zwracając szczególną uwagę na czynniki warunkujące ewolucję jego struktury funkcjonalno-przestrzennej. Zasadnicza część pracy objęła sformułowanie czterech możliwych - zdaniem autora - wariantów scenariusza rozwoju struktury funkcjonalno-przestrzennej obszaru metropolitalnego. Do każdego z nich zostały przyjęte założenia dotyczące procesu przekształceń obszaru metropolitalnego, przesłanki do zaistnienia danego wariantu, skrótowy opis rzeczywistości w perspektywie 20-letniej, która powstanie w wyniku realizacji przyjętych założeń, oraz konsekwencje wiążące się z urzeczywistnieniem danego scenariusza. Oddzielnie przy tym oszacowano konsekwencje dla systemu transportowego, społeczne, ekonomiczne oraz dla pozycji metropolii w strukturze regionu, kraju i Europy bałtyckiej. Prognozy niektórych skutków zostały celowo przerysowane, tak aby szczególnie mocno uwypuklić możliwe szanse i zagrożenia.

\section{Uwarunkowania przekształceń struktury funkcjonalno- -przestrzennej}

Punktem wyjścia dla rozważań na temat możliwych wariantów scenariusza rozwoju struktury funkcjonalno-przestrzennej obszaru metropolitalnego stała się analiza głównych tendencji obecnych przekształceń oraz ich uwarunkowań (szerzej: Lorens 2005a). Szczególne znaczenie ma tu obecna i zdeterminowana sytuacja w zakresie głównych koncentracji zainwestowania, planowane przekształcenia w dziedzinie infrastruktury transportowej oraz możliwości i tendencje przekształceń obszarów zdegradowanych. Poniżej omówiono pokrótce każde z tych zagadnień.

\section{Istniejąca struktura funkcjonalno-przestrzenna obszaru}

Obecna struktura funkcjonalno-przestrzenna obszaru metropolitalnego ma wyraźnie pasmowy charakter, zdeterminowany przez południkowy przebieg głównych układów komunikacyjnych oraz lokalizację głównych kompleksów przyrodniczych (ryc. 1). Dodać tu należy, że w przypadku metropolii trójmiejskiej uwarunkowania przyrodnicze mają kluczowe znaczenie dla kształtowania przestrzeni obszaru. Dotyczy to zwłaszcza wód Zatoki Gdańskiej, terenów Żuław Wiślanych oraz kompleksu Trójmiejskiego Parku Krajobrazowego. Te uwarunkowania fizycznogeograficzne w znaczący sposób ograniczają swobodę realizacji nowego zagospodarowania terenów położonych $w$ ich granicach lub bliskim sąsiedztwie. 
W obszarze metropolii dostrzec już można także efekty procesów suburbanizacyjnych - jak na razie głównie o charakterze suburbanizacji „wewnętrznej”.

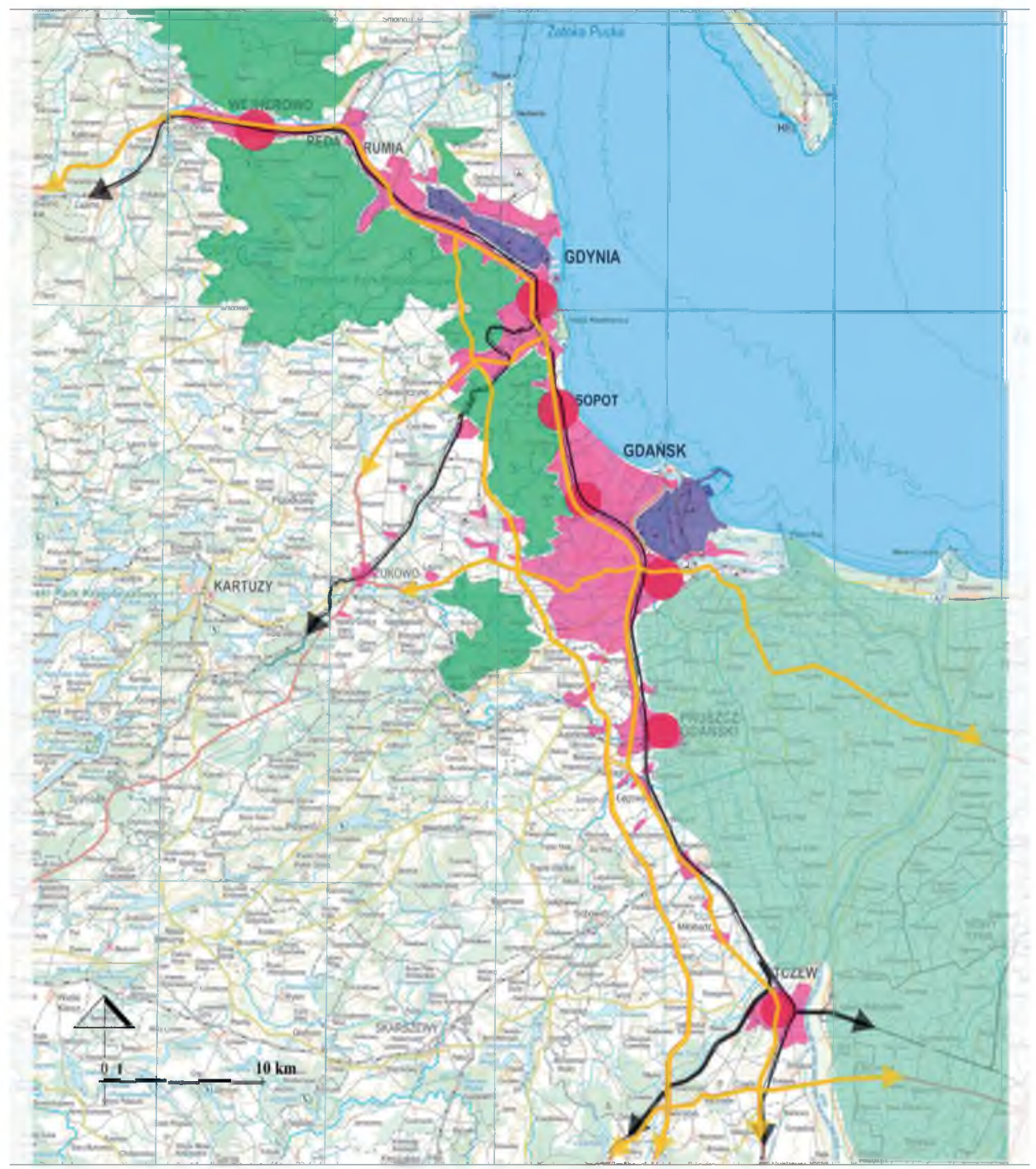

\section{LEGENDA}

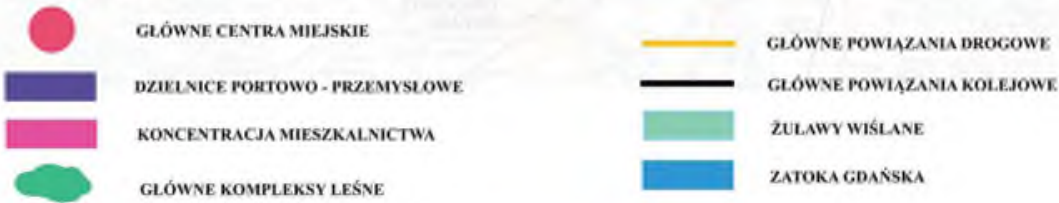

Ryc. 1. Obszar metropolitalny Trójmiasta - stan istniejący 
W szczególności odnosi się to do koncentracji nowych struktur mieszkaniowych w rejonie gdańskich dzielnic Chełm i Ujeścisko oraz gdyńskiego Chwaszczyna. Rozwój ten jest stymulowany przez realizacje powiązań komunikacyjnych o charakterze równoleżnikowym, głównie zapewniających dojazd z tzw. dolnego tarasu aglomeracji (którego osią jest ciąg al. Zwycięstwa-Grunwaldzkiej-Niepodległości-Władysława IV) do obwodnicy Trójmiasta. Jednakże realizacja tych powiązań przyczynia się także do znaczącego polepszenia dostępności komunikacyjnej rejonu tzw. górnego tarasu aglomeracji (którego osią jest właśnie obwodnica Trójmiasta).

Ewolucja obecnej struktury przestrzennej obszaru metropolitalnego nie prowadzi jeszcze do znaczącej suburbanizacji w zakresie usług, a w konsekwencji do decentralizacji funkcji centrotwórczych. Węzły komunikacyjne związane z obwodnicą Trójmiasta służą bowiem głównie lokalizacji obiektów wielkopowierzchniowych, o często wyspecjalizowanym charakterze. Oznacza to, że jeszcze nie został w sposób znaczący uruchomiony proces decentralizacji funkcji śródmiejskich, o ile przyjmiemy, iż nie zalicza się do nich handel wielkopowierzchniowy.

\section{Kierunki przekształceń i rozwoju systemu transportowego}

System transportowy metropolii składa się obecnie $z$ czterech głównych podsystemów: drogowego, kolejowego, wodnego i lotniczego (ryc. 2). Ważnym ich uzupełnieniem są rozmaite funkcje logistyczne, koncentrujące się obecnie głównie w rejonach portowych. Niezależnie od istniejących układów, szereg nowych rozwiązań $w$ tym względzie jest już wskazanych do realizacji w krótszym lub dłuższym czasie.

W odniesieniu do układu drogowego obecny system składa się głównie z dwóch osi: ciągu ulicznego Al. Zwycięstwa-Grunwaldzkiej-NiepodległościWładysława IV, i dalej wzdłuż ul. Morskiej w kierunku Wejherowa, a także z ciągu obwodnicy trójmiejskiej stanowiącej jednocześnie początek autostrady A1. Oba te układy wyznaczają w dużej mierze możliwości dojazdu do położonych wzdłuż nich osiedli i dzielnic miejskich. W zaawansowanym często stadium realizacji są połączenia poprzeczne pomiędzy tymi układami. W szczególności wymienić tu należy rozbudowywanie układu ul. Słowackiego, Armii Krajowej i tzw. obwodnicy południowej w Gdańsku. Wykonanie wszystkich tych elementów, wraz z planowanymi przebudowami w rejonie Witomina, spowoduje znaczące polepszenie możliwości komunikacyjnych pomiędzy obiema głównymi osiami aglomeracji i w zasadzie (jeśli nie liczyć planowanej także w znacznie bardziej odległej perspektywie przebudowy ul. Spacerowej) stanowi wypełnienie założeń planistycznych w tym zakresie. W stadium planowania są natomiast inwestycje umożliwiające wyprowadzenie ruchu do obszarów zewnętrznych aglomeracji: przede wszystkim wymienić tu należy tzw. obwodnicę północną (OPAT, tworzącą możliwość wyprowadzenia ruchu tranzytowego z pominięciem Rumi i Redy), nową obwodnicę metropolitalną (stanowiącą potencjalnie trzecią oś komunikacyjną na kierunku południkowym) oraz tzw. trasę kaszubską (wyprowadzającą ruch na kierunek lęborski z pominięciem pradoliny rzeki Redy). Dodatkowo w stadium zaawan- 
sowanych prac planistycznych jest tzw. Trasa Sucharskiego oraz tzw. Droga Zielona, pozwalające na zbudowanie alternatywnego dojazdu do obszarów portowych oraz dużej części dolnego tarasu aglomeracji.

Nieco inaczej wygląda sytuacja w zakresie układu kolejowego. Główna trasa wyprowadzająca ruch na kierunek Tczew i Szczecin w zasadzie przenosi znakomitą większość obciążenia ruchem pasażerskim i towarowym, przy czym nie planuje się

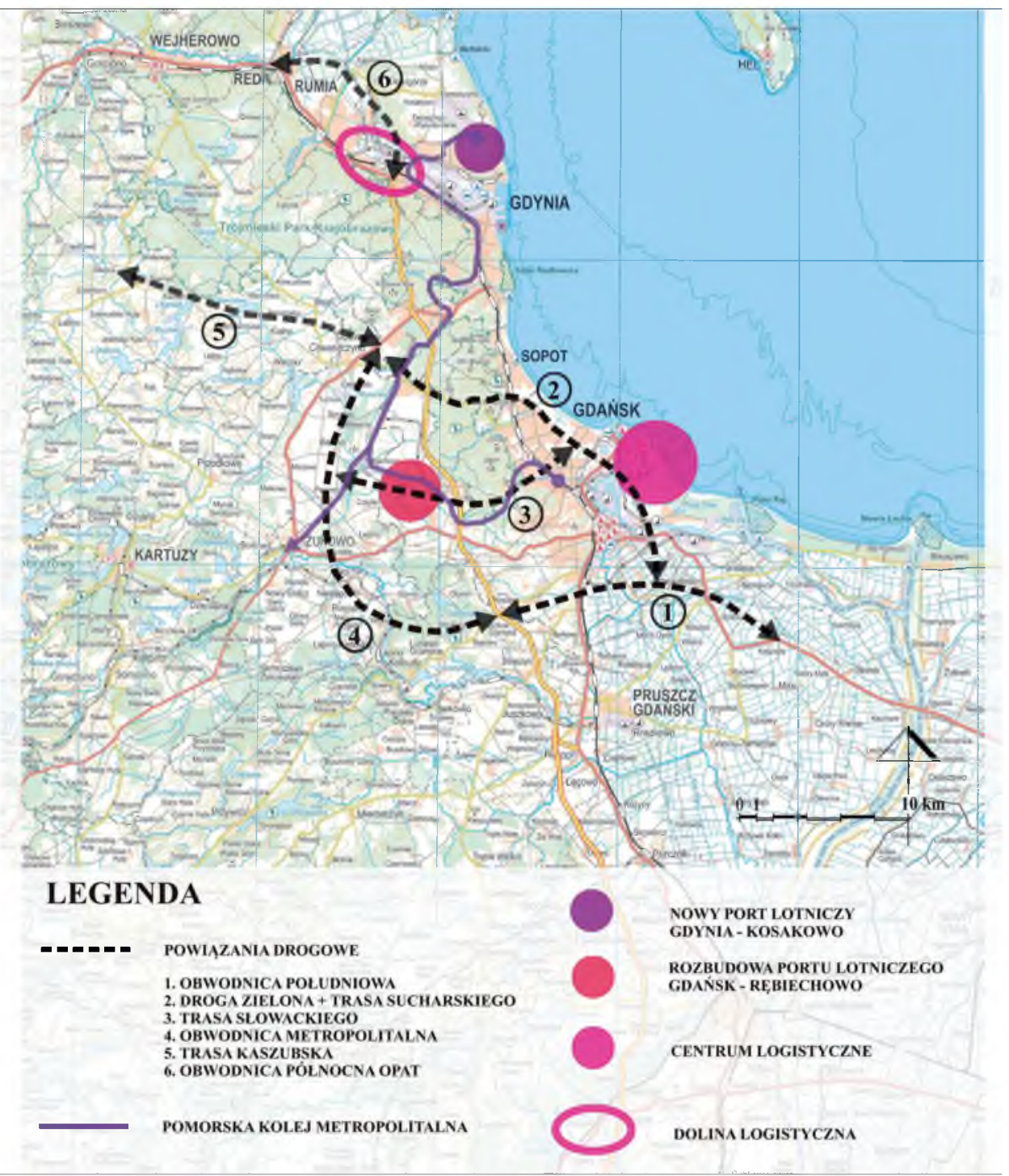

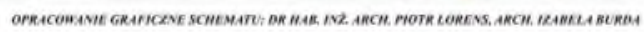

Ryc. 2. Obszar metropolitalny Trójmiasta - główne kierunki rozwoju układu komunikacyjnego i funkcji transportowo-logistycznej 
jakichś znaczących zmian w tej dziedzinie. Jedynym usprawnieniem jest podejmowana obecnie realizacja tzw. Pomorskiej Kolei Metropolitalnej, mającej stanowić możliwość dojazdu transportem szynowym do górnego tarasu aglomeracji, a przy okazji - zapewnić znacznie lepszy niż dotychczas dojazd do lotniska Gdańsk-Rębiechowo i do planowanego portu lotniczego w Gdyni-Kosakowie. Jak się wydaje, inwestycja ta z czasem stać się może główną osią transportu zbiorowego w zachodniej części obszaru metropolitalnego, co prowadzić może do stopniowej restrukturyzacji układu przestrzennego dzielnic ulokowanych na jej trasie.

Ostatnim wreszcie zagadnieniem jest przewidywana restrukturyzacja stref portowych Gdańska i Gdyni, w tym stopniowe przenoszenie przeładunków do terminali głębokowodnych. Z tymi zmianami wiązać się będzie także rozwój zorganizowanych dzielnic logistycznych, lokowanych na terenach obecnie funkcjonujących i ekstensywnie wykorzystywanych struktur portowych (patrz: Lorens 2013a). Relacje te przedstawiono szczegółowo na rycinie 2 .

\section{Kierunki rozwoju struktur mieszkaniowych i usługowych o charakterze podmiejskim}

Rozwój przestrzenny obszaru metropolitalnego wiąże się obecnie głównie z procesem nieskoordynowanej suburbanizacji, przede wszystkim o charakterze „wewnętrznym". Natomiast w odniesieniu do skutków dla obszaru metropolitalnego Trójmiasta mówić możemy o trzech podstawowych kierunkach, w tym w zakresie: urbanizacji dalekich przedmieść metropolii, rozwoju nowych struktur w granicach gmin ościennych na kierunku zachodnim i południowym oraz rozwoju nowych struktur na obszarze gmin ościennych na kierunku północnym (ryc. 3). Co interesujące, każdy z tych kierunków wiąże się z nieco odmienną specyfiką, zarówno co do rodzaju programu miejskiego, jak i dostępności terenu do inwestowania.

W odniesieniu do tendencji urbanizacyjnych na przedmieściach głównych miast metropolii mówić możemy o dwóch grupach terenów: rejonie tzw. Gdańska-Południe (obejmującego obszar pomiędzy zwartymi strukturami dzielnic Śródmieście i Orunia a obwodnicą Trójmiasta) oraz rejonie tzw. Osowa-Chwaszczyno (wiążącego się z urbanizacją terenów położonych na zachód od ciągu obwodnicy). Obszary te są obecnie dość intensywnie penetrowane przez firmy deweloperskie, co prowadzi do powstania i realizacji całego szeregu rozmaitych projektów mieszkaniowych. Mają one różny charakter i zakres, ale jedną cechę wspólną: mimo bliskiego sąsiedztwa i stosunkowo dużych wartości intensywności netto nie tworzą zwartych struktur miejskich. Jednocześnie ich realizacja często nie wiąże się z powstaniem lokalnego układu drogowego obsługującego nowy zespół inwestycji, nie mówiąc o lokalnych centrach usługowych czy obiektach celu publicznego. Tym samym obszarami usługowymi dla tych rejonów stają się centra handlowe ulokowane przy obwodnicy, a samochód osobowy - jedynym środkiem przemieszczania się.

Druga grupa obszarów możliwej ekspansji funkcji mieszkaniowych zlokalizowana jest $w$ strefie zewnętrznej aglomeracji, głównie na południowy zachód od 
terenów opisanych powyżej. Uwarunkowania geograficzne i obecny stan rozwoju sieci osadniczej powoduja, że lokowane na tych terenach struktury mieszkaniowe charakteryzują się stosunkowo dużym udziałem rozproszonej zabudowy jednorodzinnej oraz relatywnie niskimi intensywnościami netto. Jednocześnie nowo powstające struktury nie tworzą tu zwartych, odrębnych skupisk zabudowy, a raczej wiążą się z rozbudową istniejących form osadnictwa. Przykładami mogą być miejscowości takich gmin, jak Kolbudy czy Żukowo. Wyróżnić też można dwa zasadnicze skupiska inwestycji, które ciążą do tych właśnie miejscowości. Jednocześnie można je uważać za naturalne centra usługowe dla całych obszarów.

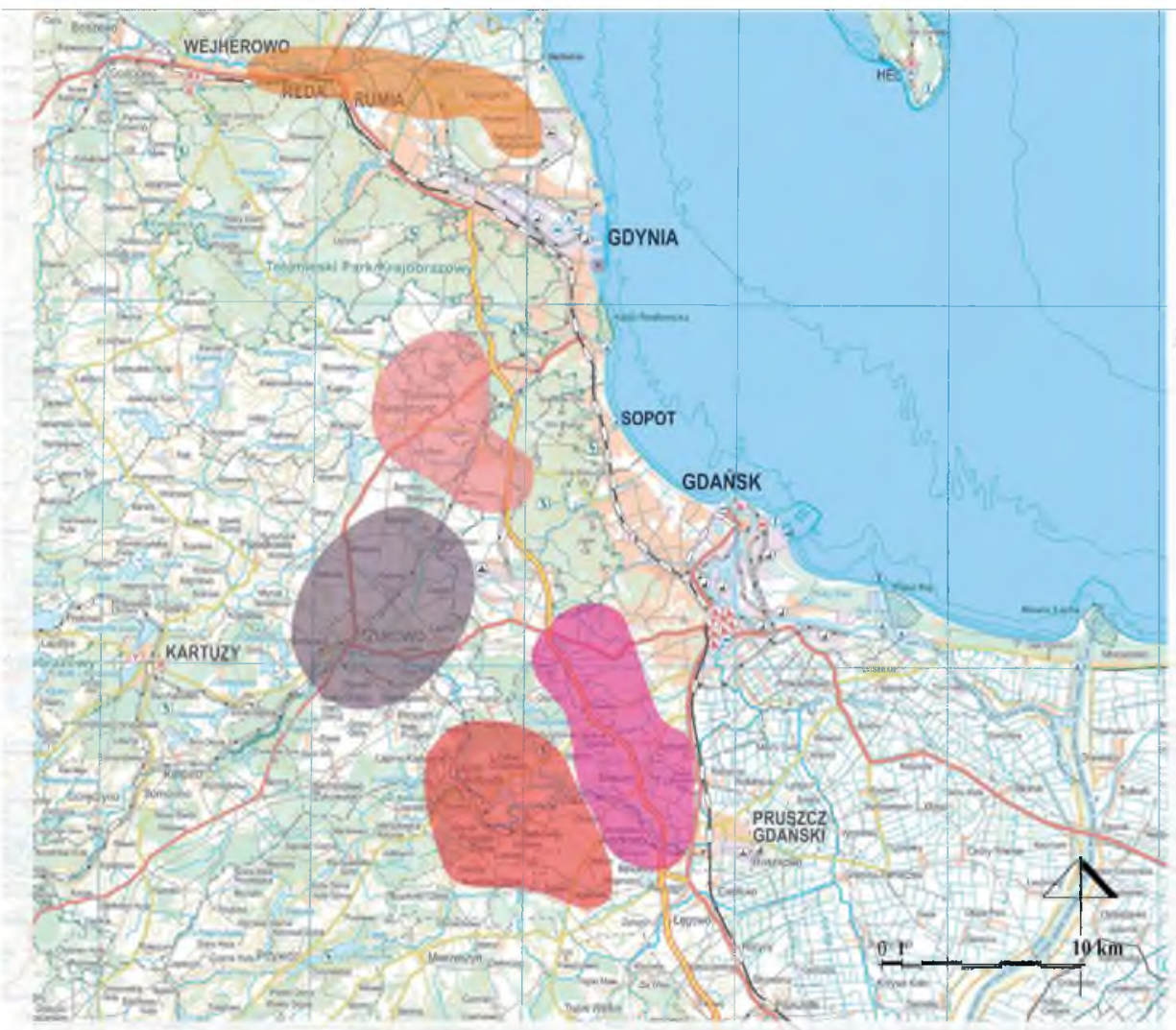

\section{LEGENDA}

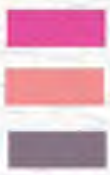

REJON GDAÑSK - POLUDNIE

REJON OSOWA - CHWASZCZYNO

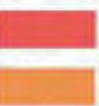

REJON ŻUKOWO

REJON KOLBUDY

REJON RUMIA - WEJHEROWO

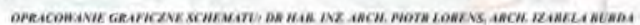

Ryc. 3. Obszar metropolitalny Trójmiasta - główne obecne kierunki rozwoju mieszkalnictwa 
Znacznie mniejsza skala rozwoju nowych struktur towarzyszy ostatniej grupie terenów ekspansji funkcji mieszkaniowej, ulokowanej na północ od Gdyni, w strefie pomiędzy doliną Redy a wybrzeżem Zatoki Puckiej. Strefa ta jest zdominowana - podobnie jak rejony Żukowa czy Kolbud - przez program jednorodzinny, natomiast - z uwagi na cenę terenów oraz atrakcyjność sąsiedztwa - uważana jest za miejsce atrakcyjne przede wszystkim dla zamożniejszej warstwy gdynian. Bliskość Gdyni i Rumii sprawia, że to ich centra dzielnicowe i ogólnomiejskie uznać by należało za obszary ciążenia mieszkańców do usług.

Podsumowując, należy stwierdzić, że procesy rozwoju nowego programu mieszkaniowego w strefie podmiejskiej Trójmiasta są dość zróżnicowane, a jednocześnie wytworzone już zostały pewne mechanizmy strukturalizacji przestrzennej tych obszarów. Ich lokalizację i relacje do rdzenia aglomeracji przedstawiono na rycinie 3 .

\section{Kierunki przekształceń obszarów zdegradowanych}

Ostatnią wreszcie grupą przesłanek związanych z określeniem wariantów scenariusza przekształceń obszaru metropolitalnego jest oszacowanie potencjału przekształceń i intensyfikacji struktur już zurbanizowanych, a więc wyodrębnienie tych, które mogą być poddane procesom głębszych przemian, i uzupełnienie o nowe, znaczące porcje programu miejskiego (ryc. 4). Dodać należy, że dotyczy to zarówno programu mieszkaniowego jak i usługowego czy rekreacyjnego, a obszary przekształceń są ulokowane często w sąsiedztwie zwartych struktur miejskich, nawet śródmieść( m.in. Lorens, Martyniuk-Pęczek 2009).

Pierwsza grupa obszarów potencjalnych przekształceń obejmuje tereny kompleksowej rewitalizacji, w tym realizacji zupełnie nowego programu miejskiego na terenach całkowicie oczyszczonych z poprzedniego zainwestowania. W obrębie Trójmiasta znajduje się bardzo dużo tego typu obszarów o różnym potencjale rozwojowym (wyrażającym się głównie w możliwej do realizacji powierzchni nowej zabudowy). Do najważniejszych ich skupisk należą koncentracje terenów poprzemysłowych, wśród których wymienić można przynajmniej cztery lokalizacje:

- Obszar Młodego Miasta w Gdańsku, z perspektywą objęcia procesem przekształceń także części Ostrowa oraz zaplecza tzw. Portu Północnego. Teren ten częściowo jest już poddawany tego typu procesom, a przemiany w zakresie profilu produkcji zakładów stoczniowych oraz planowane przeobrażenia struktur portowych dają podstawę do prognozowania rozszerzenia tych procesów na pozostałe obszary w jego granicach. Osiami tego założenia będą ul. Nowa Wałowa oraz planowana Trasa Sucharskiego.

- Obszar Letnicy i Nowego Portu w Gdańsku jest już obecnie poddawany procesom daleko idących przemian, których praktycznym wyrazem jest lokalizacja na tym terenie nowego stadionu piłkarskiego, kompleksu Targów Gdańskich oraz planowanych innych nowych inwestycji. Osiami tego założenia stać się mogą ul. Marynarki Polskiej i ul. Uczniowska, gwarantujące dobry dojazd do całości obszaru. 
- Rejon tzw. Międzytorza w Gdyni, w tym obejmujący kompleks tzw. portu wschodniego (zewnętrznego), także jest już przedmiotem kompleksowych działań o charakterze restrukturyzacyjnym. Realizowane są tu pierwsze inwestycje, a planuje się podjęcie kolejnych. Osią tego założenia stanie się ul. Nowa Węglowa.

- Rejon dawnej cukrowni w Pruszczu Gdańskim również jest już przygotowany na przyjęcie nowego, znaczącego programu, a skala tego obszaru (porówny-

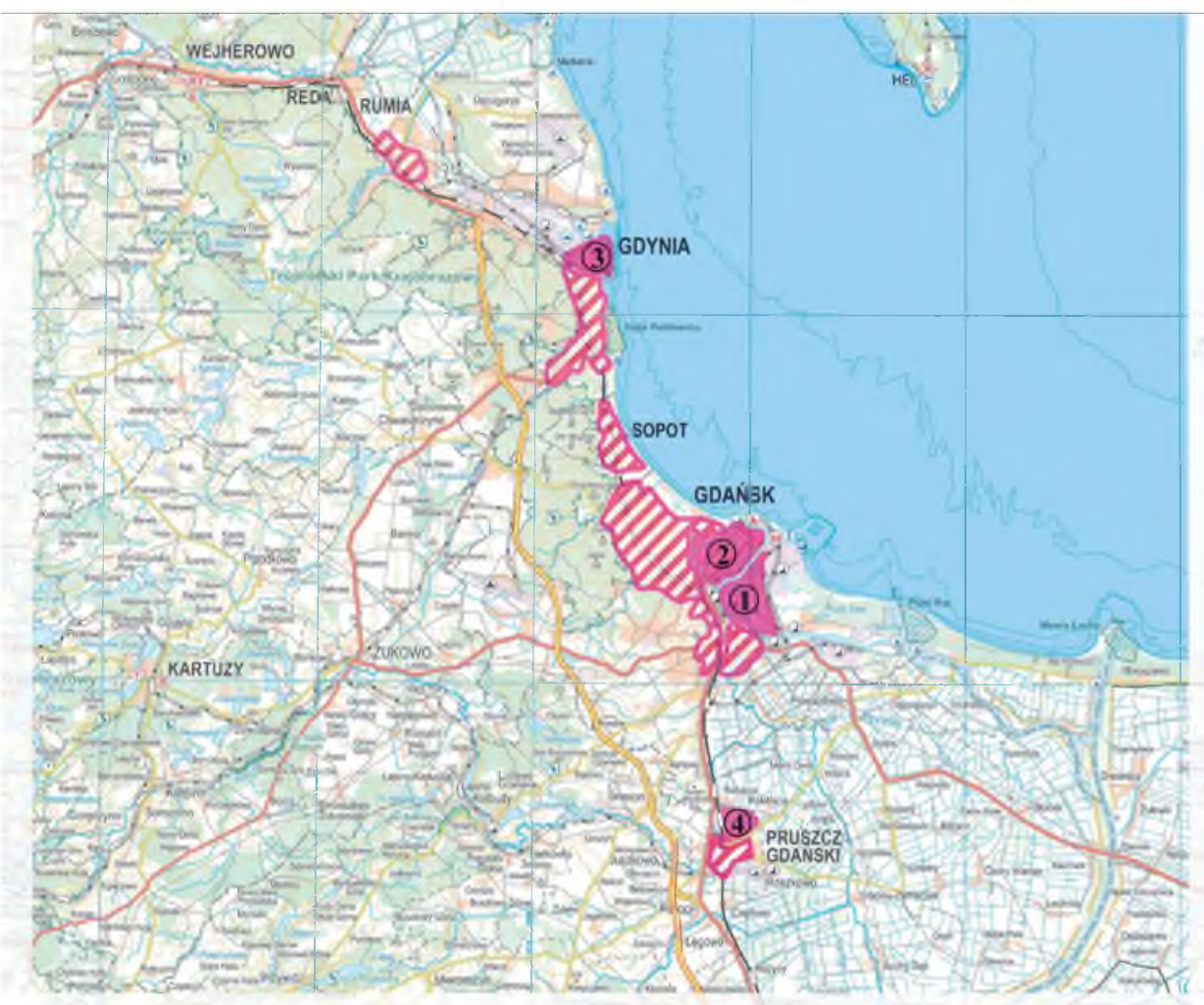

LEGENDA

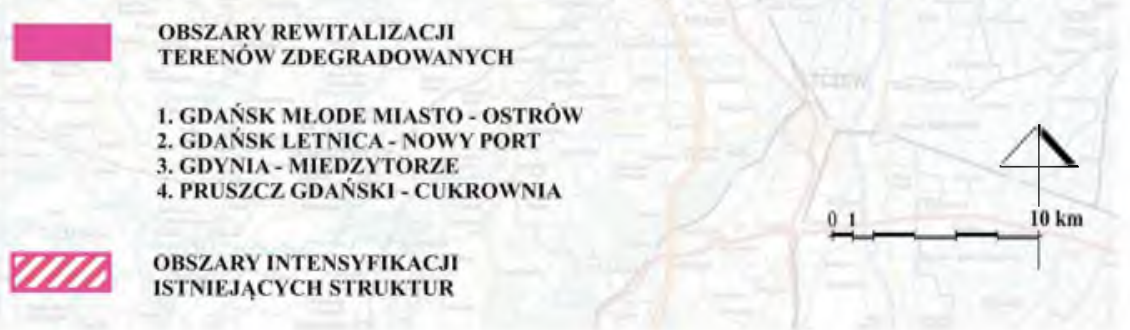

Ryc. 4. Obszar metropolitalny Trójmiasta - tereny przekształceń istniejących struktur miejskich 
walna z całym obecnym śródmieściem miejscowości) pozwala na stwierdzenie, że stać się on może jednym z najważniejszych obszarów rozwojowych południowej części metropolii.

Niezależnie od wymienionych terenów kompleksowych przekształceń, w strukturze obszaru metropolitalnego wyróżnić można szereg terenów mających warunki do intensyfikacji zagospodarowania. W odróżnieniu od obszarów kompleksowych przekształceń, zdolnych do przyjęcia znaczącego nowego programu inwestycyjnego, tereny te mogą być uzupełniane o pojedyncze inwestycje wykorzystujące wolne działki w istniejących strukturach. Do takich obszarów należy m.in. cała powierzchnia dolnego tarasu Gdańska i Gdyni, znacząca część Sopotu oraz istniejące śródmieścia Rumi i Pruszcza Gdańskiego. W znacznie mniejszym stopniu dotyczy to śródmieścia Tczewa oraz Wejherowa. Lokalizację wszystkich tych obszarów przedstawiono na rycinie 4.

\section{Wnioski do budowy scenariusza przekształceń obszaru}

Na bazie powyższych rozważań sformułować można szereg wniosków do budowy wariantów scenariusza przekształceń obszaru metropolitalnego Trójmiasta. Jednym z najważniejszych jest uznanie, że istniejąca struktura zurbanizowana obszaru metropolitalnego, a w szczególności jej najstarsza część, stać się może obszarem kompleksowych przekształceń i rozwoju, co będzie skutkować ulokowaniem w jej granicach znaczących porcji nowego programu miejskiego. Z drugiej strony, obecne tendencje rozwoju obszaru przedmiejskiego metropolii są dość zróżnicowane i pozwalają na określenie szeregu wariantów tego procesu, które zależą w znacznej mierze od przyjętego modelu inwestowania. W każdym jednak razie proces ten postępuje, a jego zobrazowaniem jest rozlewanie się struktur mieszkaniowych nie tylko $w$ rejonie obwodnicy, ale także $w$ znacznie dalej na zachód położonych fragmentach strefy przedmiejskiej.

Kolejny wniosek wskazuje, że przekształcenia struktury funkcjonalno-przestrzennej obszaru metropolitalnego są stymulowane przez nowe inwestycje komunikacyjne i infrastrukturalne, pozwalające zarówno na polepszenie obsługi terenów już zainwestowanych, jak i dopiero możliwych do inwestowania. Szczególną rolę w tym zakresie ma odegrać tzw. kolej metropolitalna, której realizacja w długim okresie przyczynić się powinna do restrukturyzacji obszarów przedmiejskich. Obszar przedmiejski - wraz z realizacją prowadzonych obecnie inwestycji - zyska także znacznie lepsze warunki obsługi komunikacją drogową. Dodatkowe inwestycje, np. tzw. obwodnica metropolitalna czy północna, przyczynią się zapewne jednak do dalszego procesu urbanizacji dalekich przedmieść aglomeracji oraz do urbanizacji terenów wiejskich, obecnie wciąż jeszcze zdominowanych przez funkcje związane z rolnictwem.

Jednocześnie moźliwe scenariusze bazować mogą na znacznie bardziej rozbudowanej gamie czynników, zależnych m.in. od przyjętej polityki rozwoju obszaru lub jej braku. Przykładem mogą tu być warianty, rozważane m.in. w planie zagospodarowania przestrzennego województwa. 


\section{Możliwe warianty scenariusza przekształceń struktury funkcjonalno-przestrzennej obszaru}

Na bazie wyników analiz sformułować można zasadnicze warianty scenariusza rozwoju w odniesieniu do obszaru metropolitalnego Trójmiasta w aspekcie jego struktury funkcjonalno-przestrzennej. Scenariusz i jego warianty zbudowano na czterech podstawowych przesłankach, które przyjmują za możliwy rozwój nowych układów drogowych i komunikacji publicznej, dominację nowych struktur mieszkaniowych o różnym charakterze, realizację przekształceń i rewitalizację obszarów zdegradowanych, dostateczny stopień kontroli nad procesami przekształceń w obrębie całości aglomeracji (patrz: Lorens 2013a).

\section{Wariantowe scenariusze przekształceń obszaru metropolitalnego Trójmiasta}

Na bazie analizy powyższych uwarunkowań sformułowano cztery wariantowe scenariusze przekształceń:

- Wariant 1 - dalszy niekontrolowany rozwój zjawiska suburbanizacji.

- Wariant 2 - zatrzymanie procesu suburbanizacji i rozwój struktur o charakterze kompaktowym.

- Wariant 3 - rozwój dualny: intensyfikacja centrum oraz rozwój dalekich przedmieść.

- Wariant 4 -zrównoważony rozwój stref centralnych i przedmiejskich.

Każdy z tych scenariuszy został szczególowo omówiony w odniesieniu do założeń przestrzennych, przesłanek niezbędnych dla jego urzeczywistnienia, opisu moźliwego stanu wynikowego oraz konsekwencji jego realizacji. Każdy został także przedstawiony w sposób graficzny.

Rzecz jasna, powyższa lista nie wyczerpuje wszystkich możliwych wariantów rozwoju przestrzennego metropolii. Jak się jednak wydaje, kolejne warianty stanowiłyby jedynie mutację przedstawionych powyżej rozwiązań. Tym samym biorąc pod uwagę bardzo duży poziom przybliżenia prognozowanej sytuacji - nie stanowiłyby one propozycji znacząco odbiegającej od zaproponowanych.

\section{Wariant 1. Dalszy niekontrolowany rozwój zjawiska suburbanizacji}

Podstawowym założeniem dotyczącym tego wariantu procesu przekształceń obszaru metropolitalnego jest kontynuacja obecnie występujących równolegle tendencji: suburbanizacji, o niekontrolowanym i fragmentarycznym charakterze, oraz cząstkowej, wyrywkowej reurbanizacji, wiążącej się z rewitalizacją i intensyfikacją wybranych przestrzeni miejskich, zwłaszcza na obszarze tzw. dolnego tarasu aglomeracji (ryc. 5). Rozwój nowych struktur przedmiejskich występować będzie głównie na dalekich przedmieściach metropolii, po zachodniej stronie obwodnicy trójmiejskiej.

Główną przesłanką do realizacji tego wariantu scenariusza jest brak znaczącej interwencji publicznej w formie kontroli procesów urbanizacyjnych, w szczegól- 


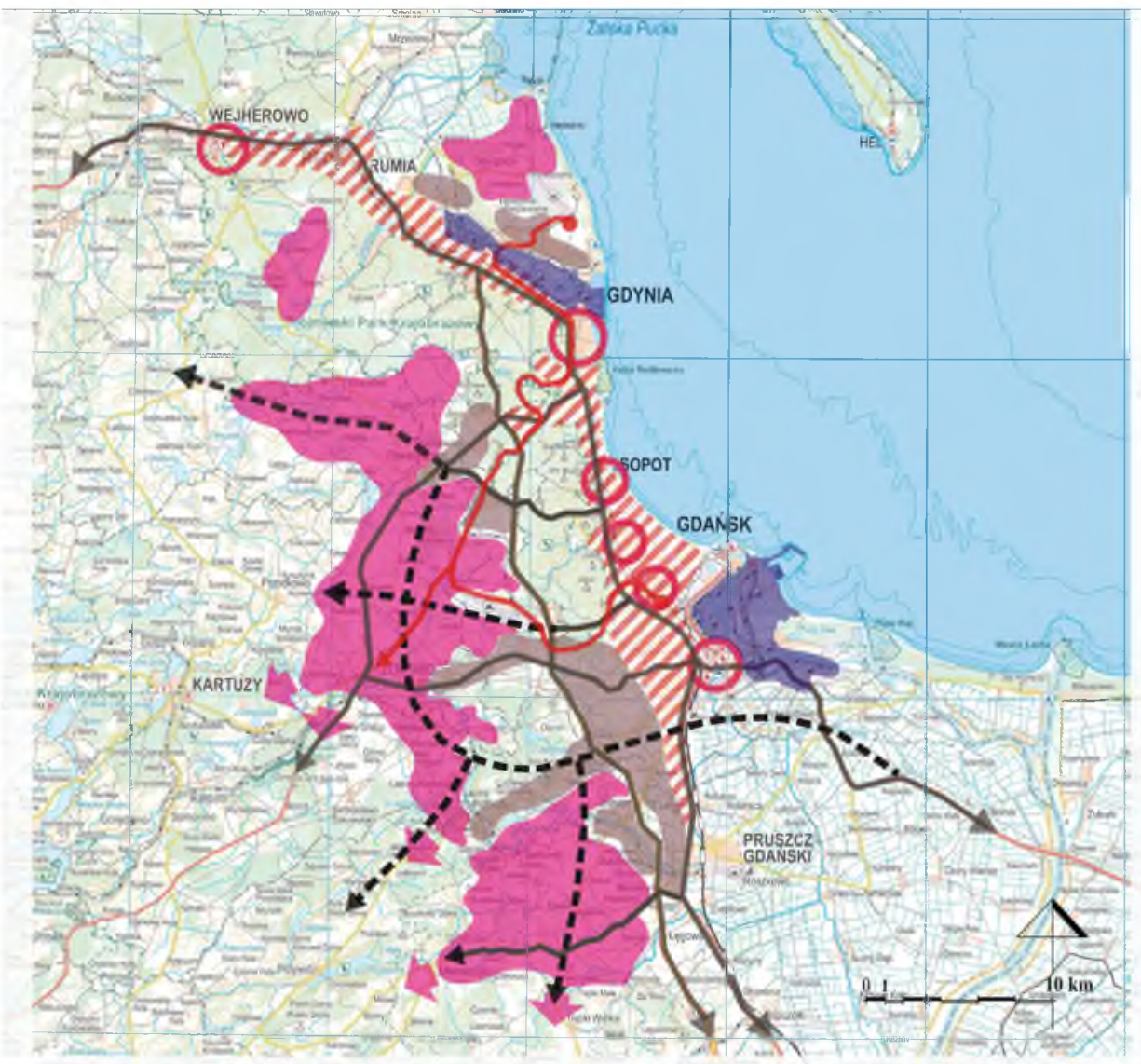

\section{LEGENDA}

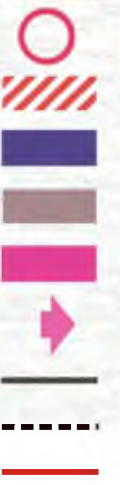

OBSZARY CENTRALNE - BIEGUNY WZROSTU FUNKCJ METROPOLITALNYCII

OBSZARY MOZLIWEJ INTENSYFIKACJI I PRZEKSZTALCEŃ TERENÓW ZURBANIZOWANYCH

OBSZARY MOZLLIWEJ INTENSYFIKACJ I PRZEKSZTALCEŃ STREF PORTOWO - PRZEMYSLOWYCH

OBSZARY DALSZEGO ROZWOJU STRUKTUR MIESZKANIOWYCH

OBSZARY DALSZEJ URBANIZAC.I STREFY ZEWNĘTRZNE.I METROPOLII

DALSZE KIERUNKI EKSPANSJI ZAINWESTOWANIA

ISTNIEJACE I REALIZOWANE GLÓWNE POWIAZANIA DROGOWE

KONIECZNOSC RE.AL.IZ.ACJI NOWYCH POWIAZAŃ DROGOWYCII

POMORSKA KOLEJ METROPOLITALNA

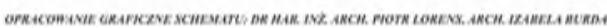

Ryc. 5. Obszar metropolitalny Trójmiasta - scenariusze rozwoju struktury funkcjonalno-przestrzennej metropolii. Wariant 1 - dalszy nickontrolowany rozwój zjawiska suburbanizacji 
ności na szczeblu lokalnym (w odniesieniu zarówno do miast tworzących rdzeń metropolii, jak i do gmin ościennych). Odnosi się to do niekontrolowanej urbanizacji przedmieść metropolii, a także braku znaczących impulsów dla kontynuacji i ewentualnego wzmocnienia procesów reurbanizacji jej jądra. Równocześnie konieczna jest przynajmniej częściowa realizacja nowej infrastruktury komunikacyjnej, zwłaszcza na terenach położonych na zachód od obecnej obwodnicy trójmiejskiej. Przesłanką istotną dla realizacji tego scenariusza będzie spowolnienie procesów restrukturyzacji terenów portowych Gdańska i Gdyni w wyniku kontynuacji obecnego modelu ich wykorzystania.

W konsekwencji zastosowania tej wersji scenariusza w perspektywie 20 lat obecny tzw. dolny taras aglomeracji ulegnie częściowej restrukturyzacji, co skutkować będzie m.in. częściową reurbanizacją i intensyfikacją istniejących struktur. Oznaczać to może realizację szeregu nowych inwestycji, jednakże o charakterze fragmentarycznym i nie tworzących nowych, znaczących skupisk programu miejskiego. Równocześnie postępować będzie proces urbanizacji rejonu Kolbud, Żukowa, okolic Kartuz oraz terenów na zachód od Chwaszczyna, przy jednoczesnej dużej fragmentacji nowych struktur. Wiązać się to będzie z powstaniem pojedynczych lub niewielkich zespołów nowej zabudowy na tym obszarze, o dość różnorodnym (choć zapewne przede wszystkim jednorodzinnym) charakterze. Będą się one lokować w zasięgu dojazdu z głównych, istniejących dziś, elementów układu drogowego. W zakładanej perspektywie czasowej zrealizowany zostanie, częściowo planowany obecnie, układ drogowy, zapewniający minimalne standardy dojazdu do tych obszarów. Jednakże inwestycje te będą miały charakter głównie lokalnych usprawnień istniejącej sieci drogowej oraz pogłębiać będą zdecydowaną dominację transportu indywidualnego w dojazdach do pracy i usług. Ewentualna realizacja tzw. obwodnicy zachodniej oznaczać będzie jej wykorzystanie jako osi komunikacyjnej dla nowo powstających dzielnic i zespołów. Nie wytworzą się także znaczące nowe centra usług, a raczej wzmocnieniu ulegać będzie sieć obecnie działających centrów zlokalizowanych w ciągu obwodnicy Trójmiasta.

Konsekwencje dla systemu transportowego wiążące się z urzeczywistnieniem się tego wariantu scenariusza oznaczają wzrastające obciążenie ruchem samochodów indywidualnych, a wykonane inwestycje jedynie w niewielkim stopniu przyczynią się do jego udrożnienia. Owe usprawnienia dotyczyć jednak będą przede wszystkim dojazdów od obszaru centralnego metropolii do ciągu obwodnicy. Natomiast układ na zachód od tego ciągu zostanie w dużej mierze zakorkowany wzrastającymi potokami ruchu. Częściowo zrealizowany układ kolei metropolitalnej obsługiwać będzie zwłaszcza dojazdy z centrum metropolii do lotniska, Osowy i rejonu Centrum Matarnia. Natomiast nie spełni on roli głównego ciągu komunikacyjnego zapewniającego obsługę przedmieść.

Istotną konsekwencją społeczną wiążącą się z tym wariantem scenariusza będzie proces segregacji spolecznej, w tym wyprowadzanie się ludzi młodszych i reprezentujących klasę średnią na obszary dalekich przedmieść. Równocześnie w niewielkim stopniu postępować będzie proces koncentracji tych grup społecznych na terenach centralnych aglomeracji - dotyczyć to będzie jednak głównie miejsc szczególnie atrakcyjnych, zwłaszcza atrakcyjnych widokowo, krajobrazowo oraz ze 
względu na sąsiedztwo specyficznych usług. Natomiast bliskie przedmieścia metropolii (rejon obecnej obwodnicy) zostaną zdominowane przez warstwy biedniejsze, spodziewać się też należy rozwoju rozmaitych patologii społecznych na tych obszarach. Dalszej degradacji ulegać będą tzw. wielkie dzielnice mieszkaniowe oraz niektóre inne dzielnice, także te już obecnie dotknięte problemami spolecznymi.

Zasadniczą konsekwencją ekonomiczną jest znaczący wzrost kosztów utrzymania infrastruktury komunalnej oraz odpływ podatników (w szczególności podatników bogatych) do gmin ościennych. Oznaczać to może duże kłopoty finansowe zarówno dla miast tworzących jądro aglomeracji, jak i dla gmin ościennych. Jednocześnie wartość nieruchomości w obrębie metropolii będzie utrzymywać się na niewiele zmienionym poziomie, a na niektórych obszarach może ulec wręcz obniżeniu.

Pozycja konkurencyjna metropolii - zwłaszcza w kontekście możliwości rozwoju nowych funkcji o charakterze ponadlokalnym, wymagająca dużej atrakcyjności środowiska zamieszkania oraz zgrupowania instytucji otoczenia biznesu - nie będzie się znacząco zwiększać, a wręcz może ulec obniżeniu. Dotyczyć to może także turystyki, w tym kongresowej i biznesowej. Pofragmentowana i powoli przekształcająca się przestrzeń metropolii nie będzie stanowić istotnego magnesu dla nowych firm, klasy metropolitalnej i innych zainteresowanych wysoką jakością życia grup spolecznych.

\section{Wariant 2. Zatrzymanie procesu suburbanizacji i rozwój struktur o charakterze kompaktowym}

Wśród założeń scenariusza w tym wariancie przewiduje się zatrzymanie procesu niekontrolowanej suburbanizacji i uporządkowanie trendów rozwojowych. Tym samym koncentrować się one będą na obszarach istniejących struktur miejskich oraz w ramach uporządkowanych struktur przedmiejskich, stanowiących dopełnienie istniejących obecnie terenów ekspansji mieszkalnictwa. Równocześnie wykształcone zostaną nowe powiązania drogowe o charakterze tranzytowym, omijające struktury zurbanizowane metropolii trójmiejskiej (ryc. 6).

Przesłanką do realizacji tego wariantu jest podjęcie przez wszystkie zainteresowane samorządy (zarówno szczebla lokalnego, jak i regionalnego) skoordynowanych i zdecydowanych działań, mających na celu zbudowanie wspólnej dla metropolii polityki przestrzennej oraz partnerstwa na rzecz rozwoju, które zakładać będzie redystrybucję w skali całego obszaru metropolitalnego dochodów płynących z realizacji skoncentrowanego zainwestowania na terenach centralnych. Równocześnie realizacja scenariusza wymaga podjęcia przez kluczowe miasta tworzące metropolię zdecydowanych działań na rzecz odnowy obszarów zdegradowanych, w tym restrukturyzacji dzielnic portowo-przemystowych oraz innych terenów możliwych przekształceń. Koniecznym uzupełnieniem tych działań stać się winna wybiórcza realizacja kluczowych elementów układu drogowego i infrastruktury transportu zbiorowego, zapewniająca przede wszystkim dogodne warunki poruszania się wewnątrz granic obszaru zurbanizowanego.

W rezultacie podjęcia opisanych powyżej działań w perspektywie 20-letniej powstanie struktura obszaru metropolitalnego o charakterze kompaktowym, 


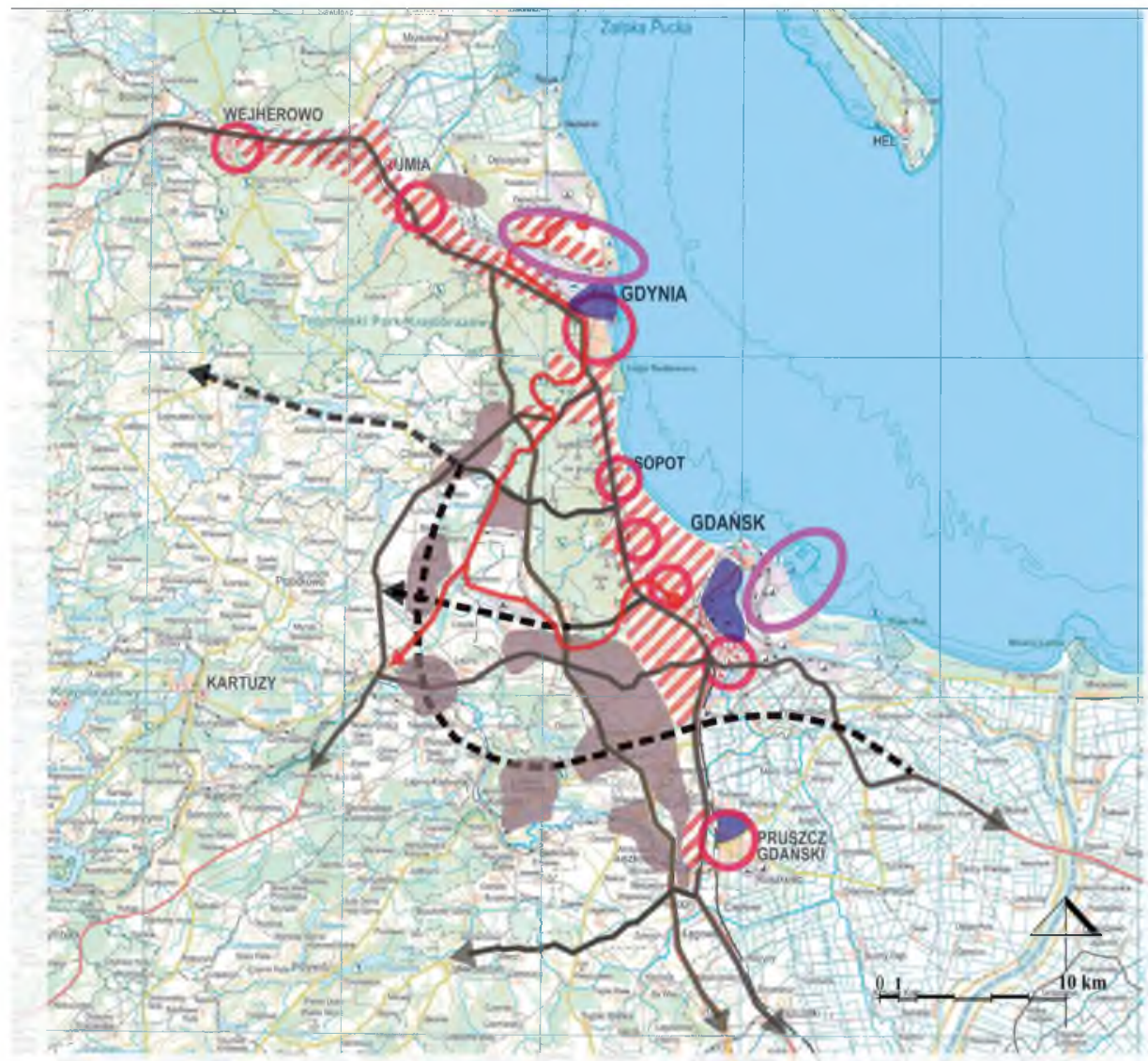

LEGENDA

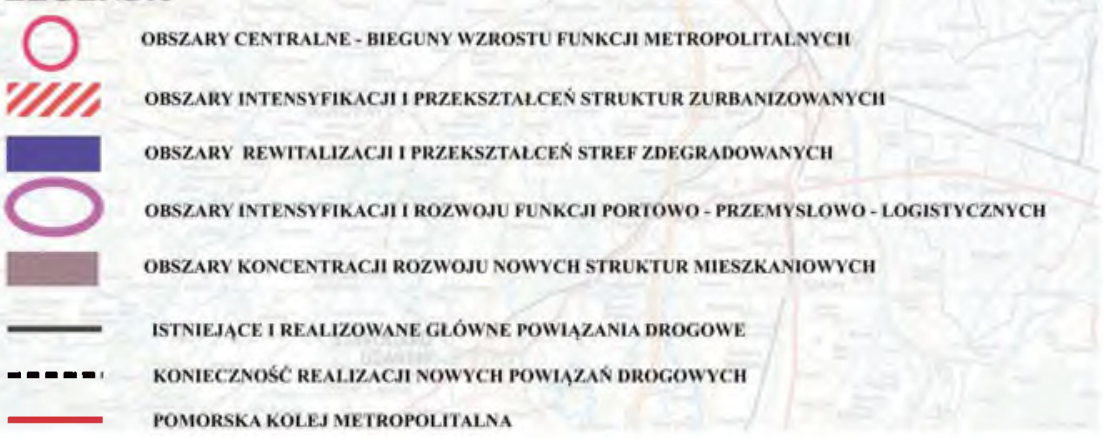

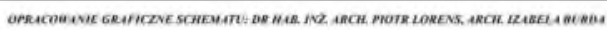

Ryc. 6. Obszar metropolitalny Trójmiasta - scenariusze rozwoju struktury funkcjonalno-przestrzennej metropolii. Wariant 2 - zatrzymanie procesu suburbanizacji i rozwój struktur o charakterze kompaktowym 
w zdecydowanej większości skupiona na terenach już zajętych na cele miejskie. Oznacza to koncentrację zagospodarowania na zachód od obwodnicy trójmiejskiej oraz znaczącą intensyfikację zainwestowania tzw. dolnego tarasu aglomeracji. Jednocześnie struktury te są dobrze obsłużone układami komunikacji publicznej oraz kluczowymi elementami układu drogowego. Możliwa do realizacji obwodnica zachodnia aglomeracji ma w tym układzie charakter tranzytowy i przejmuje rolę układu wyprowadzającego ruch poza rejon Trójmiasta. Równolegle znaczącym przekształceniom ulegają struktury portowo-przemysłowe: następuje ich specjalizacja oraz dostosowanie do nowych potrzeb, co wiąże się z ekspansją na nowe tereny (także realizacja nowych struktur na nadsypanych pirsach w głębi Zatoki Gdańskiej).

W zakresie systemu transportowego wystąpi konieczność zbudowania kompletu powiązań komunikacyjnych w strefie wewnątrzaglomeracyjnej, a więc po wschodniej stronie obwodnicy trójmiejskiej. Jednocześnie jest możliwe powstanie wybranych powiązań komunikacyjnych o charakterze tranzytowym, w tym tzw. obwodnicy metropolitalnej oraz trasy kaszubskiej. Wymuszone to zostanie znaczącym zintensyfikowaniem ruchu w obrębie istniejącego układu oraz dociążeniem obwodnicy trójmiejskiej ruchem aglomeracyjnym. W ramach tego wariantu scenariusza powstanie kolei metropolitalnej spowoduje ograniczenie konieczności znaczącej rozbudowy układu drogowego o charakterze regionalnym, przy jednoczesnym wykorzystaniu tej linii na potrzeby obsługi znacznej części ruchu pasażerskiego na terenie metropolii.

Realizacja scenariusza w tym wariancie skutkować będzie większym stopniem integracji społecznej w ramach metropolii, co zostanie wymuszone przez bliskie sąsiedztwo miejsc zamieszkania odmiennych grup spolecznych i korzystaniem przez nie $z$ tej samej infrastruktury o różnorodnym charakterze, w tym $z$ usług. Jednocześnie znacznie powszechniejsze staną się różnorodne konflikty społeczne wynikające $z$ procesów intensyfikacji zagospodarowania, np. dotyczące niechęci do zagospodarowania nieruchomości obecnie odłogowanych. W dużym stopniu natomiast istnieć będzie możliwość pełnego wykorzystania infrastruktury spolecznej, bez konieczności pilnej realizacji jej nowych elementów.

Pod względem konsekwencji ekonomicznych najważniejszym elementem stanie się silna polaryzacja w odniesieniu do struktury dochodów pomiędzy miastami i gminami położonymi w centrum metropolii oraz na jej peryferiach. Oznaczać to może narastanie konfliktów, o ile nie zostanie zbilansowane przez mechanizm redystrybucji dochodów w skali metropolitalnej. Równocześnie następować będzie naturalny proces znaczącego wzrostu wartości nieruchomości położonych na obszarze centralnym metropolii oraz relatywna stagnacja w odniesieniu do lokalizacji obrzeżnych.

W konsekwencji istnieje szansa wykreowania obszaru metropolitalnego interesującego dla środowisk biznesu oraz klasy kreatywnej, oferującego dużą dostępność wysokiej jakości przestrzeni powiązanej z dużą intensywnością życia. Tym samym znacznie zwiększa się szansa na wzmocnienie konkurencyjnej pozycji metropolii, zarówno w odniesieniu do Polski północnej (a także całego kraju), jak i regionu południowego Bałtyku. 


\section{Wariant 3. Rozwój dualny - intensyfikacja centrum oraz rozwój dalekich przedmieść}

Trzeci wariant scenariusza zakłada zatrzymanie procesu suburbanizacji bezpośrednich przedmieść aglomeracji przy jednoczesnym stymulowaniu intensyfikacji zagospodarowania jej dalekiego przedpola oraz wykreowaniu nowych biegunów wzrostu w regionie - wykorzystujących istniejące ośrodki miejskie (ryc. 7). W szczególności dotyczy to Lęborka, Kartuz, Kościerzyny, Skarszew, Starogardu Gdańskiego oraz Tczewa. Miasta te stać się mogą alternatywnymi dla centrum metropolii ośrodkami wzrostu, wzorowanymi na idei „miast satelitarnych”. Jednocześnie zostaną pomiędzy nimi wykreowane pasma rozwojowe, obejmujące kompleksy zainwestowania o zdecydowanie rezydencjonalnym charakterze. W ramach tego wariantu konieczna jest realizacja nowych, znaczących układów komunikacyjnych, zapewniających możliwość obsługi planowanych koncentracji mieszkalnictwa (w tym tzw. obwodnicy metropolitalnej) oraz usprawnienie powiązań komunikacyjnych ośrodków dziś pozostających poza strukturą metropolii. Dokonać się to może na drodze poprawy istniejącego układu o charakterze regionalnym lub też budowy trzeciej obwodnicy metropolitalnej, łączącej Lębork, Kościerzynę, Starogard Gdański i Tczew.

Przesłankami do realizacji tego wariantu będą trzy zasadnicze działania. Pierwsze polega na znaczącym ograniczeniu rozwoju strefy podmiejskiej aglomeracji wraz z wykreowaniem polityki intensyfikacji jej obecnego jądra oraz skoncentrowaniem nowych terenów mieszkalnictwa pozamiejskiego w ściśle wyznaczonych strefach związanych z Kartuzami, Żukowem, Kolbudami i Chwaszczynem. Drugie dotyczy wykreowania polityki rozwoju przestrzennego i gospodarczego ośrodków regionalnych, co wiązać się powinno z realizacją nowych miejsc pracy w granicach głównych miast położonych w odległości $60-80 \mathrm{~km}$ od obecnego Trójmiasta. Trzecią przesłanką wreszcie będzie wykreowanie znacznie lepszych powiązań komunikacyjnych pomiędzy wymienionymi ośrodkami regionalnymi a obecnym obszarem metropolitalnym, umożliwiających powiązanie wszystkich tych ośrodków w sprawnie funkcjonujący organizm. Równocześnie powstanie konieczność wprowadzenia polityki równoważenia kosztów rezygnacji z rozwoju przestrzennego gmin wiejskich, tracących na realizacji założonej koncepcji.

W konsekwencji w perspektywie 20-letniej nastąpi decentralizacja struktury funkcjonalno-przestrzennej aglomeracji, przy czym wykreowane zostaną trzy zasadnicze koncentracje funkcji miejskich. Pierwszym będzie ścisłe jądro aglomeracji, obejmujące obszary na wschód od obwodnicy trójmiejskiej; drugim, koncentracje nowego mieszkalnictwa o charakterze pozamiejskim, ograniczone do wybranych obszarów, powiązanych z podmiejskimi ośrodkami wzrostu (Kartuzy, Żukowo, Kolbudy, Chwaszczyno). Trzecią formą koncentracji będą nowe miasta satelitarne metropolii, powiązane ze sobą pasmami rozwoju, rozwijające się w oparciu o historycznie wykształcone ośrodki: Lębork, Kościerzynę, Skarszewy, Starogard Gdański, Tczew. Elementy te powiązane zostaną siecią komunikacji indywidualnej i zbiorowej, obejmującej zarówno rozbudowaną w skali regionalnej sieć kolei metropolitalnej, jak i poprzez system dwóch lub trzech obwodnic metropolitalnych. Niezależnie od ekspansji funkcji mieszkaniowych, restruktu- 
ryzacji poddane zostaną tereny portowo-przemysłowe aglomeracji, z prawdopodobnym przeniesieniem znaczącej większości tego typu aktywności na obszary

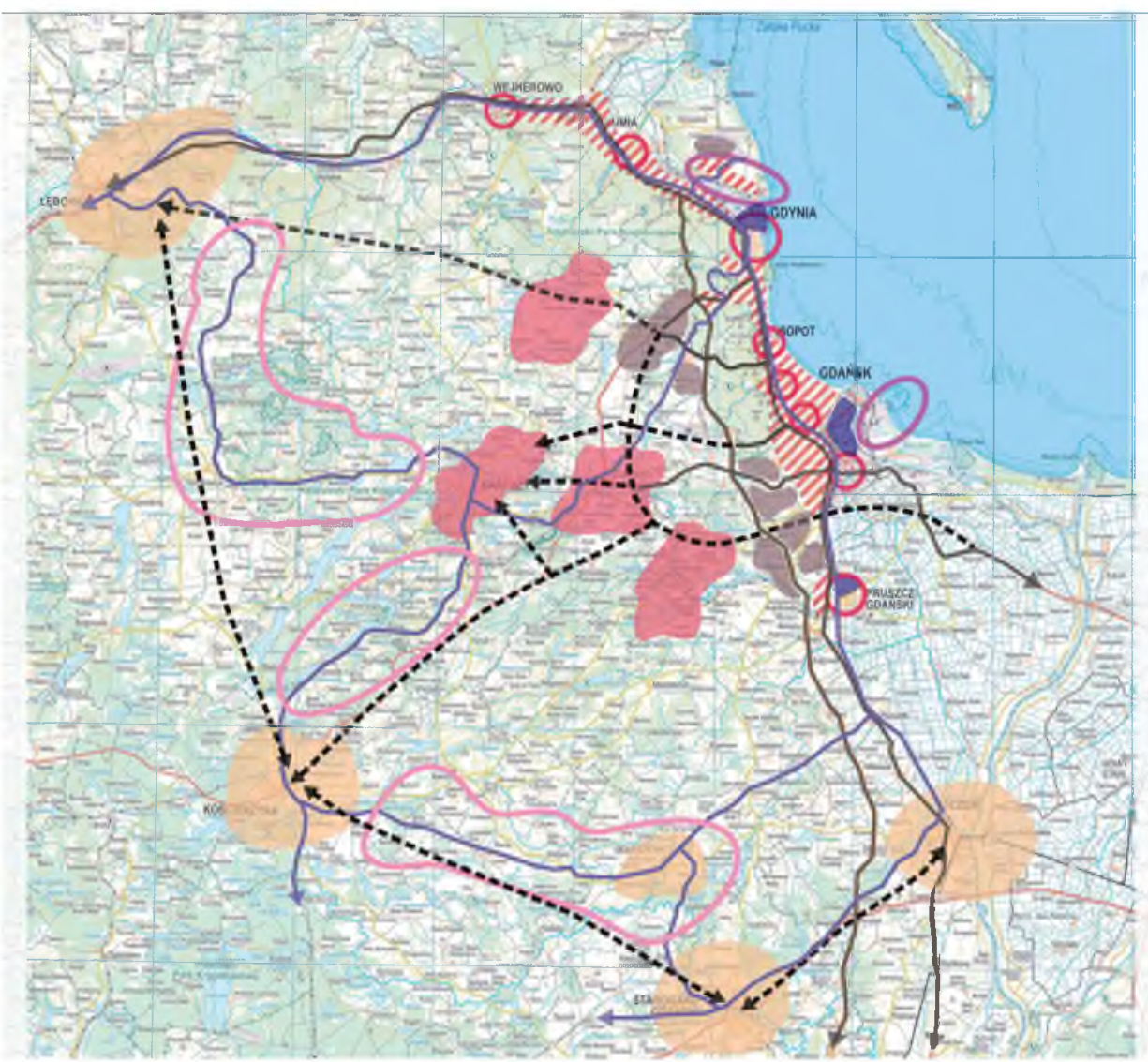

LEGENDA
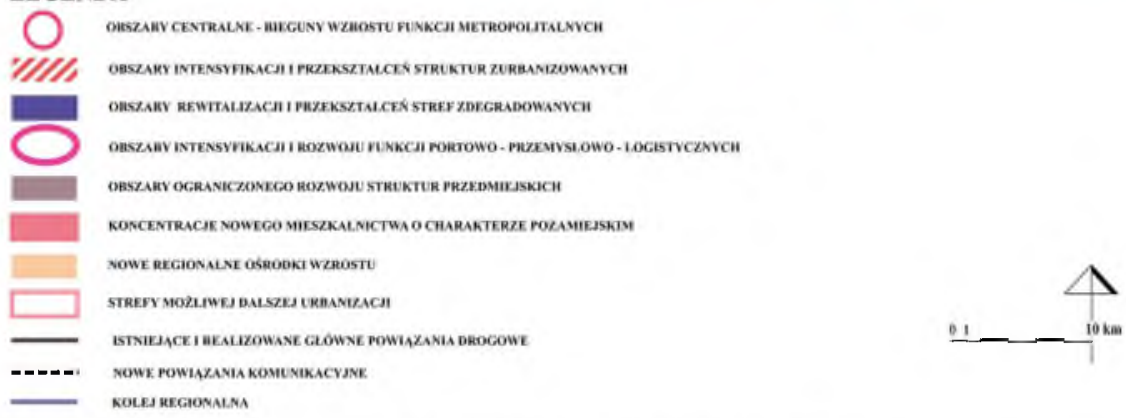

Ryc. 7. Obszar metropolitalny Trójmiasta - scenariusze rozwoju struktury funkcjonalno-przestrzennej metropolii. Wariant 3 - rozwój dualny - intensyfikacja centrum oraz rozwój dalekich przedmieść 
nowo realizowanych terminali głębokowodnych i związanych z nimi obiektów zaplecza logistycznego.

W odniesieniu do systemu transportowego, znaczące rozbudowanie obecnej sieci drogowej i kolejowej, zapewniające dogodne warunki przemieszczania się pomiędzy elementami zdecentralizowanej struktury przestrzennej metropolii. Co istotne, większość tych powiązań będzie mieć charakter tranzytowy wobec obszarów pomiędzy wykreowanymi biegunami wzrostu, co nie wywoła znaczących impulsów rozwojowych dla tych terenów.

Opisane w tym scenariuszu przekształcenia w zakresie konsekwencji społecznych dają szansę na wykreowanie silnych społeczności lokalnych nowych miast satelitarnych, budowanych w oparciu o silne tradycje lokalne i tożsamości miejsca.

W kategoriach ekonomicznych realizacja scenariusza wiązać się będzie ze znaczącymi wydatkami na rozwój ośrodków regionalnych oraz rozbudowę powiązań infrastrukturalnych pomiędzy nimi. Wydatki wynikać będą także z polityki redystrybucji efektów ekonomicznych rozwoju na obszary gmin wiejskich. Wykreowanie nowych biegunów wzrostu pozwoli na znaczące wzmocnienie gospodarcze regionu i przełamanie monopolistycznej pozycji Trójmiasta na polu rozwoju nowoczesnego przemysłu i związanych z tym korzyści.

W relacjach zewnętrznych może nastąpić strukturalne wzmocnienie ekonomiczne i społeczne regionu jako całości, jednakże kosztem wzrostu samego jądra metropolii. Oznaczać to może zaprzepaszczenie szansy na rozwój Trójmiasta jako znaczącej metropolii bałtyckiej, przy jednoczesnym utrzymaniu silnej pozycji (a nawet jej wzmocnieniu) przez cały region.

\section{Wariant 4. Zrównoważony rozwój stref centralnych i przedmiejskich}

W czwartym wariancie scenariusza zakłada się równoległe procesy intensyfikacji zagospodarowania jądra obszaru metropolitalnego oraz koncentracje nowego zainwestowania wzdłuż pasm rozwojowych związanych z istniejącymi korytarzami transportowymi oraz pozaaglomeracyjnymi ośrodkami wzrostu (ryc. 8). Oznaczać to będzie wzmocnienie pozycji Kolbud, Żukowa i Kartuz oraz rozwinięcie wzdłuż tras komunikacji kołowej i kolejowej prowadzących do nich, nowych pasm rozwojowych, związanych ze skoncentrowaną zabudową mieszkaniową, usługową i ewentualnymi strefami logistycznymi. Rozwój ten wpisywać się będzie w planowaną sieć powiązań komunikacyjnych obszaru metropolitalnego, w szczególności w układ obwodnicy metropolitalnej i kolei metropolitalnej.

Decydującą przesłanką do realizacji tego scenariusza jest zaistnienie zrównoważonej polityki rozwoju regionalnego, promującej zarówno intensyfikację struktur jądra metropolii, jak i koncentrowanie nowego zainwestowania wzdłuż wybranych ciągów infrastruktury komunikacyjnej. Polityka ta winna być zrównoważona mechanizmami powstrzymującymi niekontrolowany rozwój na pozostałych obszarach potencjalnej ekspansji struktur mieszkaniowych. Konieczne jest tu działanie wieloaspektowe: na szczeblu jądra metropolii, gmin tworzących wybrane pasma rozwojowe oraz pozostałych terenów aglomeracji.

W perspektywie 20-letniej powstanie struktura o dużym stopniu zwartości, koncentrująca się wzdłuż wybranych, znacząco usprawnionych ciągów komunika- 


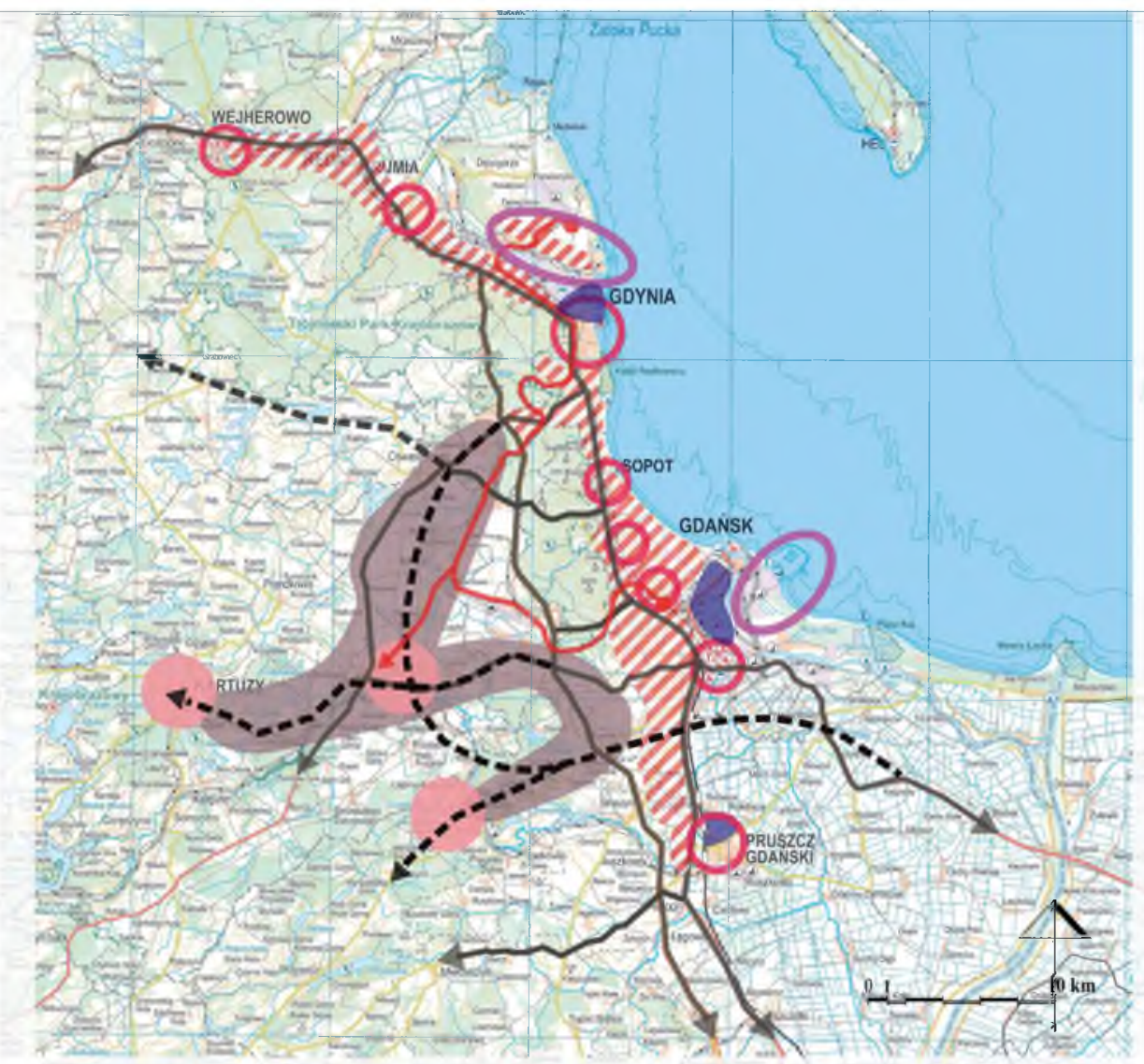

LEGENDA

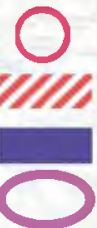

OBSZARY CENTRALNE - BIEGUNY WZROSTU FUNKCJI METROPOLITALNYCH

OBSZARY INTENSYFIKACJI I PRZEKSZTALCEŃ STRUKTUR ZURBANIZOWANYCH

OBSZARY REWITALIZACJI I PRZEKSZTALCEŃ STREF ZDEGRADOWANYCH

OBSZARY INTENSYFIKACJI I ROZWOJU FUNKCJI PORTOWO - PRZEMYSLOWO - LOGISTYCZNYCH

INTENSYFIKACJA ISTNIEJACYCH OŚRODKÓW POZA OBSZAREM METROPOLITALNYM

PASMA ZORGANIZOWANEGO ROZWOJU STRUKTUR MIESZKANIOWYCH

ISTNIEJĄCE I REALIZOWANE GLÓWNE POWIĄZANIA DROGOWE

- - KONIECZNOŚĆ USPRAWNIENIA POWIAZAŃ DROGOWYCH

POMORSKA KOLEJ METROPOLITALNA

OPRACOWANIE GRA FICZNE SCHEMATU: DR HAB. WZZ, ARCH. PIOTR LORENS, ARCH. IZABELA BUROA

Ryc. 8. Obszar metropolitalny Trójmiasta - scenariusze rozwoju struktury funkcjonalno-przestrzennej metropolii. Wariant 4 - zrównoważony rozwój stref centralnych i przedmiejskich 
cyjnych, przy dominującym wykorzystaniu komunikacji publicznej. Zwornikami tej struktury staną się podlegające także istotnym procesom przekształceń $\mathrm{i}$ intensyfikacji miejscowości podmiejskie (Kolbudy, Zukowo, Kartuzy, Chwaszczyno). Ich struktura przypominać zacznie kompaktowe w swym charakterze miasta satelitarne, nie będące jednakże znaczącymi, samodzielnymi ośrodkami wzrostu. Staną się one raczej regionalnymi centrami usług i swoistymi „terminalami końcowymi" ciągów komunikacyjnych metropolii. Realizacja scenariusza wiązać się będzie ze znaczącym ograniczeniem procesu rozwoju nowego zainwestowania na pozostałych terenach otoczenia aglomeracji.

System transportowy wymagać będzie poważnego usprawnienia wybranych ciągów komunikacji drogowej i kolejowej, a także realizacji zupełnie nowych elementów tego systemu zgodnie z przyjętym układem przestrzennym. Jednocześnie ograniczona zostanie realizacja innych powiązań infrastrukturalnych, w tym zapewniających komunikację z pozostałymi głównymi ośrodkami regionu.

W zakresie konsekwencji społecznych wzmocnieniu ulegnie jednorodność struktury społecznej metropolii, a mieszkańcy przedmieść uzyskają status pełnoprawnych jej obywateli. Ograniczony może też zostać proces alienacji społecznej poszczególnych grup społecznych oraz negatywne konsekwencje gentryfikacji i gettoizacji.

Skutki ekonomiczne realizacji scenariusza obejmować będą znaczące zyski związane $z$ efektem koncentracji nowych miejsc zamieszkania i pracy, w tym płynące $z$ dużo lepszego wykorzystania przestrzeni jądra obecnej metropolii. Natomiast istotne nakłady będzie należało ponieść na stworzenie wysokiej klasy infrastruktury komunikacyjnej, obsługującej te struktury, oraz na realizację ewentualnej polityki równoważenia efektu koncentracji wzrostu w odniesieniu do pozostałych terenów gmin ościennych.

Przyjęcie tego wariantu scenariusza doprowadzić może do wzmocnienia konkurencyjnej pozycji metropolii w kontekście regionalnym, krajowym, a nawet międzynarodowym. Odnosi się to do stworzenia wysokiej jakości środowiska miejskiego w obrębie jądra obecnej metropolii, polegającego na koncentracji atrakcyjnego programu miejskiego oraz interesujących przestrzeni miejskich, jak też uformowania pasm rozwojowych o wysokim stopniu uporządkowania przestrzeni. Jednocześnie rozwój ten pozwoli na wykreowanie jednej marki, jaką stać się może metropolia Trójmiasta w skali międzynarodowej.

\section{Wnioski końcowe}

Cztery przedstawione warianty scenariusza przekształceń struktury funkcjonalno-przestrzennej metropolii trójmiejskiej dają pogląd na przebieg i efekt tych procesów w perspektywie najbliższych 20 lat. Realizacja analizowanych wariantowo modeli rozwojowych uzależniona jest jednak od całego szeregu czynników. Należy do nich nie tylko stworzenie odpowiedniej infrastruktury, ale konieczność podjęcia trudnych decyzji politycznych na szczeblu lokalnym i regionalnym. Jak jednak pokazują przedstawione warianty, są to działania konieczne, których za- 
niechanie prowadzić może do obniżenia pozycji metropolii trójmiejskiej na forum krajowym i międzynarodowym. Sprzyjać może temu, obserwowana od jakiegoś czasu, pewna marginalizacja regionu pomorskiego na mapie powiązań gospodarczych i społecznych kraju. Brak wyboru któregoś z wariantowych rozwiązań przyczynić się może do zaprzepaszczenia ciągle jednak istniejących szans rozwojowych.

Przedstawione warianty scenariusza nie obejmują szczegółowej prognozy przestrzennej oraz wyliczeń o charakterze ekonomicznym. Jednakże pozwalają na wstępne oszacowanie wysiłku finansowego i organizacyjnego, wiążącego się $\mathrm{z}$ ich realizacją. Jest jednak wskazane, aby przed podejmowaniem dalszych decyzji w tym względzie przeprowadzić nieco bardziej pogłębione analizy tych zagadnień, opierając się na szczegółowej analizie obecnej polityki planistycznej poszczególnych gmin oraz występujących w nich tendencji rozwojowych. Bez dokładnych informacji pochodzących od samorządów nie da się dokonać racjonalnej oceny możliwości aplikacji poszczególnych scenariuszy.

\title{
Literatura
}

Kozłowski S. (red.) 2006. Żywiołowe rozprzestrzenianie się miast, Wydawnictwo Ekonomia i Środowisko, Białystok-Lublin-Warszawa.

Lorens P. (red.) 2005. Integracja i dezintegracja obszarów metropolitalnych, Urbanista, Warszawa.

Lorens P. (red.) 2005. Problem suburbanizacji, Urbanista, Warszawa.

Lorens P. 2013. Obszary poportowe - problemy restrukturyzacji. Instytut Studiów Regionalnych, Szczecin.

Lorens P. 2013. Równoważenie rozwoju przestrzennego miast polskich, Politechnika Gdańsk, Gdańsk. Lorens P., Martyniuk-Pęczek J. (red.) 2009. Wybrane zagadnienia rewitalizacji miast, Wydawnictwo Urbanista, Gdańsk.

\section{Urban development scenarios of the Tri-City Metropolitan Area}

\begin{abstract}
The article deals with the issue of shaping the spatial and functional structure of the TriCity Metropolitan Area. It includes considerations associated with conditions and possible scenarios of urban development pattern as well as with the possible consequences of the these pre-defined scenarios. Analysis of the existing development conditions includes the outlook of the present and already determined (i.e. by on-going development and infrastructure projects) urban structure of the metropolitan area, description of the planned transportation infrastructure interventions as well as tendencies in re-using and transforming of the decayed areas, including large concentrations of the brownfields. On this basis four most probable future development scenarios were drafted. Description of each of these includes definition of the spatial structure, factors required for its implementation, analysis of the possible results and their consequences. These analyses are concluded with set of final remarks associated with definition of elements influencing the "real" future development scenario and with consequences of their selective presence/implementation.
\end{abstract}

Key words: Tri-City Metropolitan Area, suburbanization, sustainable development, compact city, development scenarios 